\title{
DAVID ELLERMAN: HELPING PEOPLE HELP THEMSELVES
}

\author{
(The University of Michigan Press, Michigan, 2005. 334 o.)
}

\section{NAGYHÁZI GYÖRGY}

Először néhány szóban érdemes magával a sorozattal (Evolving Values for a Capitalist World - A kapitalista világ kialakuló értékei) is foglalkozni, melynek keretében Ellerman munkája megjelent. A michigani egyetem sorozata olyan gondolatokat igyekszik közreadni, amelyek alapját képezik egy jobb kapitalizmusnak, annak korrekciójára megoldásokat javasolnak. A sorozat első kötete: „Csináljunk, úgy mintha a jövő számítana" egy olyan tanulmánygyüjtemény, amely azt az alapvető hiányosságot elemzi, miszerint a jővó dimenziója a piaci tranzakciók (különösen az USA gazdaságában) többségének külsô (externális) tényezője. A második kötet Severin T. Bruyn munkája a „Civil gazdaság”, mely a cégek azon gyakorlatait és intézményi ösztönzőit írja le, amelyek azokat a társadalmi szükségletekkel és célokkal való összhangra sarkallják. A harmadik tanulmánykötet „Legális de nem helyes: a jogi ipar kártékony társadalmi kỏvetkezményei" címmel a jelenlegi kapitalizmus társadalomellenes gyakorlatait írja le, a fegyverkereskedelemtöl a gyorsétkeztetésig.

E sorozat részeként jelent tehát meg David Ellerman könyve, aki hosszú éveket töltött a Világbank szolgálatában, és egy időben Joseph Stiglitz tanácsadójaként dolgozott ugyanott. A sorozat szerkesztỏje (Neva Goodwin) szerint Ellerman a gazdasảgi élet legmélyebb rétegére fókuszál: azon kulturális értékekre, amelyek meghatározzák azokat az intézményeket, amelyek támogatják a gazdaságot. A Szerzó kimondott célja, hogy a fejlesztés filozófia alternatív elméleti alapjait rakja le.

Ellerman azt vizsgálja, hogy a változás - ami mindenfajta fejlesztéspolitika lényegét képezi -, mikor és milyen esetekben tartós és fenntartható. Válasza egyszerú és mondhatni banális: a fenntartható változásnak nem kívülröl, hanem azok közül kell erednie, akik „változnak”, tehát olyannak kell lennie, amilyet ök akarnak, és nem valami olyasminek, amit a donorok (a tanárok, közösségszervezök, terapeuták vagy menedzserek) mondanak nekik, hogy mit kellene akarniuk.

A kötet kiinduló feltételezése, hogy az utóbbi ötven évben a gazdaságfejlesztés gyakorlata sok esetben karikatúra kapitalizmusokat eredményezett, melyek a kapitalizmus egy lebutított és sematikus elképzelésén alapultak. Ezt a sematikus képet sok esetben olyan nagy szervezetek, mint a Világbank még tovább egyszerủsítették, és még tanácsokat is adtak országoknak ennek bevezetésére. Ez a leegyszerüsített fejlesztéspolitikai elképzelés olyan piacot képzelt el, ami soha sehol sem létezett, és az emberi viselkedésnek is olyan leegyszerúsített képletét használta, amely csak a legönzóbb motivációkon alapult. 
Ezeken az elvi alapokon törvényszerủen nem születtek megfelelö jogi rendszerek, szociális, egészségügyi és oktatási ellátórendszerek. A megfelelően müködő kapitalista rendszer további elengedhetetlen összetevőkön nyugszik, amelyeket a nagy nemzetközi szervezetek által használt redukált modell nem vett számításba: bizalom, becsületesség, a jó munka elvégzésének presztízse és a közösség jólétéhez való értelmes hozzájárulás jóérzése.

Ellerman könyve elején leszögezi, hogy a könyv címében is megtalálható szlogen: „segítsünk az embereknek, hogy magukon segíthessenek", bár rendkívül sok szervezet számára képezi alapvető küldetésük részét, akár jelmondatuk is, és annak ellenére, hogy szinte rutinszerüen használják a gazdaságfejlesztő szervezetek, ez gyakorlatukban „segítsünk az embereknek” szintre redukálódik. Ezekben a szervezetekben fel sem merül a gyanú, hogy a segítség lehet „nem segítség” is, mivel gyakori az, hogy a segítség aláássa az önsegitö képességét egy közösségnek. Ellerman szerint a valódi segítség nem valami olyasmi, ami direkt és frontális, mint valami mérnöki projekt. Nem lehet arra kényszeríteni valakit, hogy spontán módon viselkedjen, másképpen szólva: nem lehet kívülről motivációkat adni valakinek, hogy azok mentén cselekedjen, mintha azok saját motivációi lennének. Pénzért nem lehet szerelmet venni, csak szerelmesnek tűnő viselkedést. Olyan fejlesztéspolitikai alapok kialakítása a cél, amely elsődlegesen az önsegítést segíti. A Szerző ennek elméleti alapjául elsősorban Albert Hirscman munkásságát tekinti.

Ellerman a fejlesztés/fejlődés célját Amartya Sen, Martha Nussbaum és Sabine Akire nyomán a következöképpen definiálja: Növekedés vagy a gazdagság növelése (mint ami mondjuk olajmezök felfedezése, vagy más természeti erőforrásé) nem lehet a cél; a cél a fejlỏdés, mint szabadság, vagy autonómia, - a képességeket alapvetőnek tekintő nézeteknek megfelelöen - a saját szükségletek kielégítéséhez szükséges képességek és tudás megléte. Ennek elérésében az autonómia cél és eszköz is egyben. Amartya Sen terminológiájában: a szabadságnak konstitutív és instrumentális szerepe is van. Ebböl következöen a Szerzö a fejlesztési segítség kulcselemének (kulcs faktorának) az autonómia tiszteletén alapuló segítséget tekinti. Ezzel kapcsolatban megjegyzi: az utóbbi fél évszázadban a fejlődés kulcselemének keresése során először a tőke akkumulációt, különösen az infrastrukturális tőkét a szállításban, energetikában és az informatikában tekintették elsődlegesnek; majd sok frusztrációt követően az oktatás (a humántőke-felhalmozás), az egészség és az alapvető szükségletek kielégítése, míg a legutóbbi időkben a kormányzás került előtérbe, mint kulcselem (korrupció szintje). Véleménye szerint a közgazdasági fejlesztés elmélet (development economics) kulcselem keresése a fejlesztési segitségnyújtás felöl nézve valójában a rossz kérdés feltevése volt.

A Szerző az autonómia tisztelő fejlesztési segítségnyújtás alapjait két „soha ne tedd” és három „ezt csináld” tanács mentén építi fel. Az első „soha ne tedd" tanács szerint „,ne aknázd alá az önsegítő képességet társadalmi tervezéssel” (social engineering). Erre példaként a Világbank hitelezését hozza fel, ahol a hitel tárgya a „reform”, a strukturális kiigazítási programok, cserébe világbanki hitelekért, ami sziszifuszi munkának bizonyult sok esetben, amikor is az érintett országok nem voltak 
Tér és Társadalom 23. évf. 2009/2. 253-269. p.

képesek visszafizetni a kölcsönt, újra - nagyobb - kölcsönt kaptak, és további technikai segítséget a „reform” sikeres befejezéséhez, és a program végül kudarcba fulladt.

Ennek elkerülése csak az indirekt, „autonómia tisztelö" módszer segítségével lehetséges. Az autonóm cselekvés saját belsö motiváción alapszik, míg a külső motiváció nem hoz eredményt (a lovat levihetjük a folyóig, de nem tudjuk kényszeríteni, hogy igyon is). A változás tervezett előidézése külső ösztönzők segítségével általában sikertelen, azonban a nagy nemzetközi gazdaságfejlesztő szervezetek belső struktúrája csak ennek a direkt módszernek az alkalmazását teszi lehetővé. Ugyanis sokszor megesik, hogy a segélyre várók nagyon jól el tudják játszani a reform iránti elkötelezettségüket, - a segélyező szervezet ezt el is hiszi, sőt saját „eredményessége" bizonyítása miatt késztetést is érez erre -, a kívánatos változás pedig nem következik be. A Szerzỏ véleménye szerint minél nagyobb, befolyásosabb és gazdagabb egy segélyező/fejlesztỏ szervezet, annál kevésbé képes indirekt módon segíteni, ebből következően a több ez esetben kevesebb lesz. Azaz nagy összegü segítség kicsi eredményt produkál, míg az indirekt segítség esetében a kisebb segítség nagyobb eredményt hoz.

A Szerző második „soha ne tedd” tanácsa: ne ásd alá az önsegitő képességet jótékony segélyezéssel. Ez abban az esetben történik, ha a segítỏ a segélyezettet arra motiválja, hogy maradjon is a jelenlegi „nem kívánatos” állapotában, mivel ha ebböl a helyzetből kitörne, akkor elveszítené a segélyt. Ebben az esetben a segélyezettnek esze ágában sincs változtatni, hiszen ez az állapot teszi a segélyre jogosulttá. A Szerző szerint ez történt a Világbank segélyezi gyakorlatában a szub-szaharai országok esetében. Ilyen csapdahelyzetnek tekinti a szerző az AIDS-el kapcsolatos segélyezés némely aspektusát is. A segélyezés elöállíthatja azt a morális veszélyt, amikor a segélyezettek nem is tudják már elképzelni az életüket a segély nélkül.

A segélyezés szküllája és khraibdüsze tehát a felvilágosult társadalmi tervezés és a jótékony segélyezés, mely mindkettő a segélyezettek önsegítő képességét ássa alá.

A Szerző első „ezt tedd" tanácsa a következő: Indulj el onnét ahol a „cselekvők” vannak. Véleménye szerint akkor szokott az első legalapvetőbb hiba történni, amikor az utópista társadalmi tervezés iránt elkötelezett felvilágosult reformerek tiszta lappal akarnak elindulni, azaz nem vesztegetnek időt és energiát a meglévő „,rosszul müködö, elmaradott és olykor gonosznak" minősített intézmények átalakítására, azokat csak mint az átalakítási programot akadályozó tényezőkként veszik számba. Ilyen érvek hangzottak el a gazdasági átalakítási sokkterápia híveitől (Jeffrey Sachs) a 1990-es évek elején. A Szerző véleménye szerint a szervezetek nem „ugranak", nincs nagy ugrásra lehetőség az oktatásban sem, a forradalmi változás csak arra jó, hogy a már esetleg elindult evolutív folyamatokat megakassza. A segélyezőnek/fejlesztőnek képesnek kell arra lennie, hogy megtalálják a már meglévő „erényeket", amelyekre építve a társadalmi-gazdasági fejlödést katalizálni lehet.

A második „ezt tedd" tanács: nézd a dolgokat a „cselekvők" szemén keresztül. A fejlesztő szervezetek gyakran esnek abba a hibába, hogy mindenkinek ugyanazt a receptet írják fel, ugyanazt mondják, mintha nem kellene azokat a sajátos helyi körülményekhez igazítani. Meg kell tanulniuk a segítöknek, hogy a segítettek szemüvegén keresztül lássák a világot, hasonlóképpen Pólya György tanácsaihoz, misze- 
rint olyan kérdéseket kell a tanárnak feltennie, amelyek felvetődhettek a diákokban, ha az aktív tanulást akarja előmozdítani és nem olyanokat, amelyek a tanár nyilvánvalóan nagyobb tudását bizonyítják. Ha úgy látjuk a dolgokat, ahogyan a diákok, és onnét indulunk, ahol ők tartanak, azt nevezi Pólya belső segítségnek, amely sokkal hatékonyabb a külső ,deus ex machina” szerü segítségnél, amely csak arra jó, hogy összezavarja a diákokat.

A harmadik ,ezt tedd" tanács szerint mindig tartsd tiszteletben a segítettek autonómiáját. Ez a tanács tulajđonképpen összefoglalja a fejlesztési asszisztencia célját: az autonóm fejlődés elősegítését. Ez mutatja meg a mérnöki és a fejlesztési feladatok különbözőségét, hiszen ez utóbbi nem csak a környezet megváltoztatására irányul, hanem arra is, hogy az emberekben iđézzen elö változást (képesek legyenek az önállóságra).

A Szerzö téziseinek elméleti megalapozása meglehetősen alapos és széles körü. A külső és belső motivációkkal kapcsolatos nézetek áttekintése kapcsán rámutat a homo economicus-nak, a közgazdasági irođalomban használatos emberképnek (az ember lehetőség-maximalizáló ösztönzök által motivált lény) a korlátaira, miszerint ez az elképzelés rendszerint homályban hagyja, hogy az ösztönzés forrása vajon külső vagy belső? Ennek a kérdésnek szerinte alapvető a fontossága a segítő-segített kapcsolatokban. A külső és belső motivációknak helyére kell kerülniük az autonómiát tiszteletben tartó segítségnyújtás során, és mindig a belső motivációt kell az előtérbe helyezni, míg a külső motivációra (kényszer) inkább csak a háttérben van szükség. A segélyező és nemzetközi fejlesztő szervezeteknek általában megvan a saját prekoncepciójuk arról, hogy mi számít erénynek, és megpróbálnak ,erényt vásárolni" azzal, hogy különféle feltételeket támasztanak a segítségért cserébe, hogy ezt az általuk elképzelt erényes viselkedést létrehozzák. Az esetek döntő többségében valójában csak az erény látszatát kapják meg. Az autonómiát tiszteletben tartó segítségnyújtás a már meglévő belső motiváción alapul, és azt kell, segítse, hogy az erényes viselkedés útjában álló akadályokat sikerüljön lebontani, így mozdítva elő azt. A legjobb mód egy belsô motiváción alapuló reform folyamat biztosítására egy adott országban nem annak elindítása, hanem annak megtalálása.

A Szerző néhány esetet elemez is, illusztrálanđó a direkt módszer sikertelenségét és az indirekt, evolutív módszer sikerességét. Két legalapvetőbb példája Kína és Oroszország. Kína egy saját utat követve, indirekt módszereket használva sikeres lett, mig Oroszország piaci sokkterápiája hatalmas visszaesést és társadalmi leépülést okozott. Az olyan sikeresnek mondott sokkterápia eseteket elemezve, mint Lengyelország példája, rámutat, hogy annak sikere a sokkterápia mellett alkalmazott saját, az inđirekt módszer elveit követő gyakorlatoknak inkább volt köszönhető. A kuponos privatizáció esetét elemezve rámutat: az a legkevésbé sem érte el a kívánt eredményt, inkább csak politikai, semmint gazdasági haszna volt, míg a reprivatizációk gyakorlatából is inkább csak a negatívumok maradtak meg már középtávon is. Mivel a reprivatizáció elvéti az első lépést (,ott kezdd, ahol a cselekvők vannak"), hiszen a szocializmus alatt már kialakult tulajdonviszonyokat és használatokat nem veszi figyelembe. Ellerman szerint egyébként a privatizáció célja a 
társadalmilag legelfogadhatóbb „de facto" tulajdonosi jogok felé való közelítés, amely az azt létrehozó állampolgárok pozitív erőfeszítéseit elismeri, és egyúttal megpróbálja kompenzálni a múlt büneit, elismerve, hogy a történelem nem állítható meg és nem kezdhetö újra.

Erre példaként a több volt szocialista országban, köztük Magyarországon lezajlott lakásprivatizációt hozza fel, mert az ennek során követett gyakorlat felel meg leginkább a privatizáció fenti követelményeinek.

A magyar olvasó számára több oldalról nézve is tanulságos olvasmány Ellerman könyve. Elméleti keretet ad a privatizáció társadalmi hasznosságának megítéléséhez egyfelől, másfelől pedig egy teljesen új perspektívába helyezi a térség gazdasági átalakulását. $\mathrm{Az}$ olvasónak az az érzése, hogy korábbi homályos sejtései és rossz érzései utólagosan igazolást nyertek és világossá váltak. A jelenben zajló gazdasági válságot követően kialakuló gazdasági viszonyok minden bizonnyal azokra az értékekre és eredményekre is alapulnak majd, amelyeket e könyv feltárt és elemzett. A honi és az európai fejlesztéspolitika alakítói számára rendkívül hasznos elméleti és gyakorlati megfontolások valóságos tárháza David Ellerman könyve. 